\title{
Knappable materials in the Criș Valley, Romania
}

\author{
Otis N. Crandell \\ Babeș-Bolyai University, Geology Department, Cluj-Napoca, Romania. Email: otis.crandell@ubbcluj.ro
}

\begin{abstract}
:
The purpose of this study is to identify and characterise some of the raw materials in the Criș Valley, in the Apuseni Mountains, Romania which are suitable for knapping tools. The materials cropping out in this area include: siliceous sinter, agate, and silicified wood. The basic characteristics of the materials, obtained by macroscopic and petrographic investigations, provide a reference database useful in provenance studies on individual artefacts or whole assemblages. An assessment of each material is made regarding its quality as a knappable material.
\end{abstract}

Keywords: knappable material; lithic tools; siliceous sinter; agate; silicified wood; lithotheque; Apuseni Mountains; Romania

\section{Introduction}

Knowledge of the potential geological sources for knappable materials in a certain area is of great importance in archaeology, in particular when studying production and trade of lithic tools in prehistory. In order to determine which artefacts were imported, it is first necessary to understand which artefacts could be of local origin, especially in the case of materials of similar appearance. In many cases though, the local raw materials are rarely described in details in the archaeological literature.

The aims of this paper are to identify and characterise materials of mineral origin outcropping out in the Criș Valley, within the Apuseni Mts., central-western Romania (Figure 1), which may be suitable for knapping tools. It is intended that the information and example images presented here will be of use in provenance studies of lithic assemblages from the study area. The data may be used as references to which artefacts can be compared. The samples collected during this study are part of a larger lithotheque and will also be of use in future sourcing studies. Being able to compare artefacts with samples of potential raw materials helps to narrow down possible sources (Turq 2005).

The geological background of this area has been covered in numerous other publications (for example, see Ianovici et al. 1969; Ianovici et al. 1976; Savu 1980; Cioflica et al. 1981; Ghiurcă 1981; Savu 1983; Săndulescu 1984; Mârza et al. 1989; Balintoni 1997).

Published by the School of History, Classics and Archaeology, University of Edinburgh ISSN: 2055-0472. URL: http://journals.ed.ac.uk/lithicstudies/

This work is licensed under a Creative Commons Attribution 2.5 UK: Scotland License. 


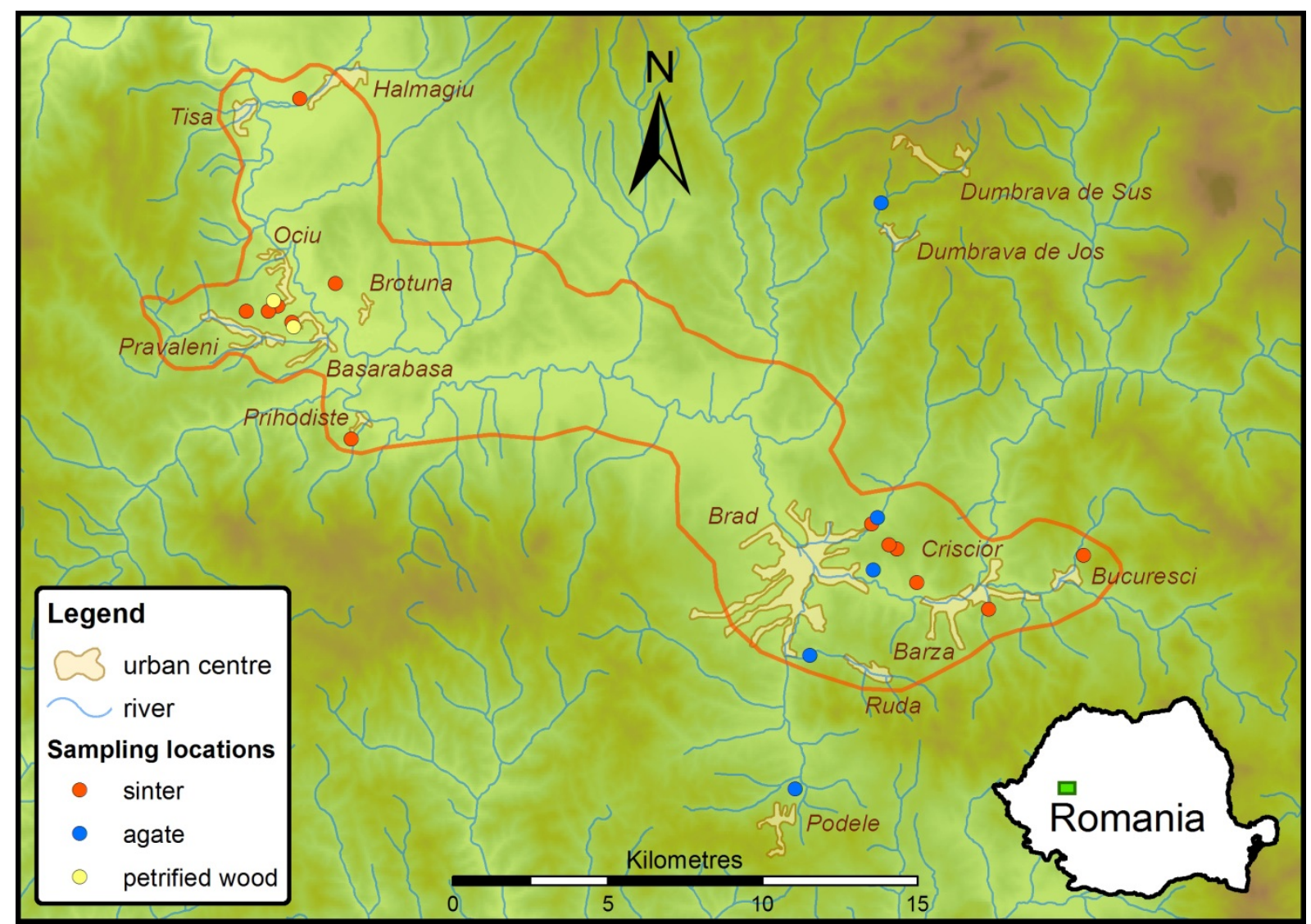

Figure 1. Map showing the study area. The general source area for Criș Valley sinter is outlined in orange. Locations where samples were collected are marked (see the legend for explanations). The inset in the lower right shows the location of the area within Romania as a green rectangle. Relief map produced from data provided by the SRTM (2000).

\section{Materials}

\subsection{Criș Valley sinter}

The origin of the Criș Valley sinter material is associated with the Neogene volcanics and their hydrothermal effect on the environment. Underwater, silica-rich, hot springs led to the deposition of a silica rich solution (epithermal) in small limnic basinets and the formation of a silica gel throughout the Brad-Hălmagiu depression, upper basin of the Criș Alba River. This is evidenced by the presence of fossilised mollusc shells and pond plants remains embedded in the silica and substituted by $\mathrm{SiO}_{2}$. This material (opal-A) hardened and began to transform into opal-CT and eventually microcystaline quartz. The same silica rich waters also lead to the silicification of wood at some locations in the basin (Voiteşti 1934: 182; Socolescu 1944: 99; Dimitrescu 1958: 101-102; Ghițulescu \& Borcoș 1966; Ghițulescu et al. 1968; RussoSăndulescu et al. 1976: 168-171; Berbeleac et al. 1982; Ștefan et al. 1982: 146-150; Borcoş et al. 1986; Ghergari \& Ionescu 1999; Ghergari et al. 1999; Mârza \& Constantina 2000).

The most well-known source is north-east of Brad (Hunedoara County) on Măgura Hill (also known as Măgura Bradului Hill) near the sanatorium (Figures 1 and 2), where several lens-like deposits are found within a level of the Neogene andesitic pyroclastics (Ghiţulescu et al. 1968; Ghergari \& Ionescu 1999; Ghergari et al. 1999; Constantina \& Pop 2003). This occurrence of the material is relatively large. The lenses are $10-30 \mathrm{~m}$ thick and range up to $0.01 \mathrm{~km}^{2}$ in surface area (Ghergari et al. 1999). The environment rich in iron and manganese hydroxides with an uneven spatial distribution lead to a wide variation in colour of these rocks. The most common colours are varying hues of yellow and red, as well as greys and 
black. Green although uncommon is occasionally observed (Ghergari \& Ionescu 1999; Ghergari et al. 1999; Mârza \& Constantina 2000). The mineralogical composition of this material has been described in detail by Ghergari and Ionescu (1999) who showed that contained granular microcrystaline quartz, microfibrous quartz, and cristobalite-tridymite opal.

The same material can be found in the Neogene pyroclastic andesites level throughout that area of the Criș Valley (see Figures 1 and 2). Other than Brad, the material can also be found near Hălmagiu, Brotuna, Ociu, Basarabasa, Prăvăleni, Crișcior, Barza, Prohosdiște and Bucureșci. Smaller outcrops occur at many more locations (Bleahu et al. 1964; Bordea \& Borcoș 1972; Mârza \& Constantina 2000; Bulgariu et al. 2005). This material is also referred to as 'geyserite'.

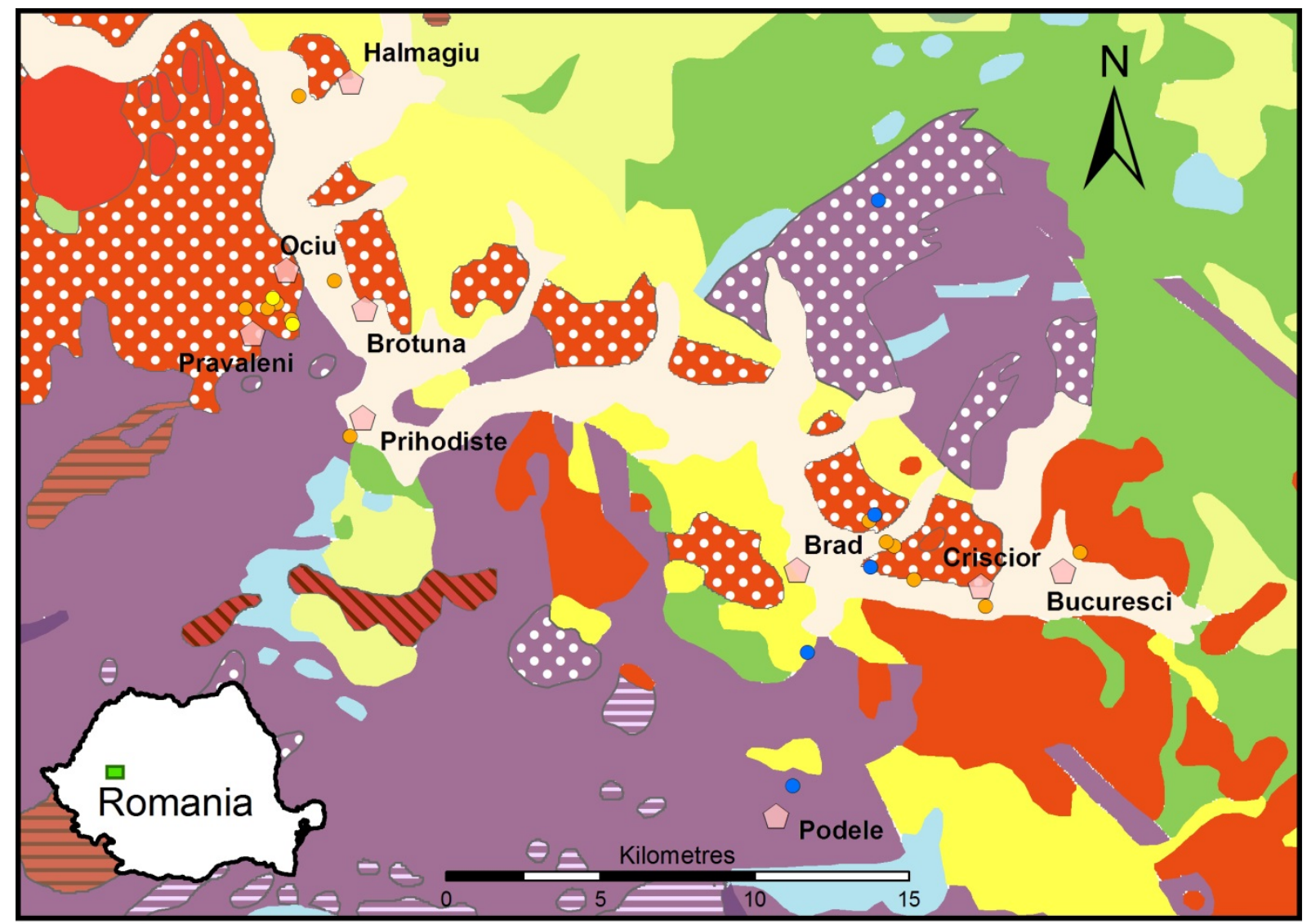

Sampling locations

sinter

Bedrock

- agate

silicified wood

$\square$ city or town

1

\begin{tabular}{|l|l|}
3 & 5 \\
4 & 6
\end{tabular}
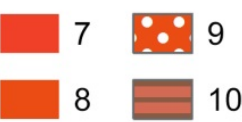

MI 11
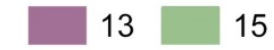

Figure 2. Simplified geological map of the Criș Valley and locations where raw materials were sampled. Bedrock legend: 1. Holocene; 2. Pliocene; 3. Miocene; 4. Upper Cretaceous; 5. Lower Cretaceous; 6. Upper Jurassic; 7. Permian; 8 \& 9. Neogene andesites and andesitic pyroclastics; 10 \& 11. Upper Cretaceous granodiorites, diorites \& monzonites; 12. Upper Jurassic IAV; 13 \& 14. Mid Jurassic ophiolitic basalts; 15. Paleozoic; 16. Cambrian. The inset in the lower left shows the location of the area within Romania as a green rectangle. Based on Săndulescu et al. (1978) modified by Tudor (2009) and the author of this study.

\subsection{Other materials (agate and silicified wood)}

Agate and silicified wood do not appear to have been used much (or at all) to make tools at archaeological sites in this area. For this reason, they will not be discussed in as much detail as sinter. They are mentioned here mainly for comparison with similar materials from 
other regions which may have been used for tool making and because it is also possible that artefacts of these materials might later be found in the area.

\section{Agate}

Banded chalcedonies (whether parallel or concentric) are called agates (Flörke et al. 1982; Graetsch et al. 1985; Heaney \& Davis 1995; Moxon \& Reed 2006; Moxon et al. 2007). Chalcedony, although technically a form of microcrystalline quartz, has a somewhat different micro-structure and may form differently. Chalcedony has a fibrous fabric, being formed of tiny bundles of fibres $<1 \mu \mathrm{m}$ thick, which radiate out from the surface where deposition started, as opposed to most chert which has a microstructure of interlocking grains or crystals randomly oriented. For an introduction and detailed discussion of particle shapes, see Zingg (1935), Sneed and Folk (1958), Graetsch (1994) and Blott and Pye (2008).

Many researchers have suggested that agate banding forms as a result of crystallisation from siliceous hydrothermal fluids with varying levels of silica saturation and trace element concentrations (Flörke et al. 1982; Heaney 1993; Heaney \& Davis 1995). Folk and Weaver (1952) believe that chalcedony is usually directly precipitated into cavities and cracks, and that crystallization begins at a few centres spaced along such a surface. Banding may be caused by various factors such as fluctuation in trace element content (e.g., iron), pauses in the crystallisation process, changes in pressure and silica content and textural changes. The most common host rocks for agates are fine-grained volcanics, e.g., basalts, basaltic andesites, rhyolites, dacites.

There are various sources of agate within the study area but they are sporadic (see Figures 1 and 2). As with the above mentioned sinter, the agates are formed due to hydrothermal processes in the Neogene volcanics. Whereas the sinters were deposited in basins, the agates formed within cracks in their parent rocks. This material within the study area has been discussed by previous authors (see, for example, Ghiţulescu et al. 1968; Ghiurcă 1981; Mârza \& Constantina 2000). There are numerous samples of agate and chalcedony in general in the collection of the Museum of Mineralogy at Babeș-Bolyai University in Cluj-Napoca.

\section{Silicified wood}

There are remains of highly silicified wood in the area between Ociu, Prăvăleni and Basarabeasa (Figures 1 and 2), for example, at Culmea Cremenii - which means "Chert Peak" in Romanian - near the town of Prăvăleni). This material is of Neogene age (Lupu et al. 1966). The origin of this silicified wood is related to the geothermal events and the silica rich which formed the sinter from this region. This material occurred due to opal replacing the wood material and often filling in the micro-pores in the wood to create a more solid material. They are often found embedded in Neogene volcanic tuffs (Ghițulescu \& Borcoș 1966; Ghițulescu et al. 1968; Borcoş et al. 1986; Mârza \& Constantina 2000). This materials and its sources have been presented in detail by previous authors (for more details, see Nagy \& Mârza 1967; Petrescu \& Nuţu 1969; 1970; 1972; Givulescu 1997; Iamandei \& Iamandei 1997; 1999; Ghiurcă 2000; Iamandei \& Iamandei 2000; 2001; Alcalde-Olivares 2002; Nagy et al. 2002; Iamandei et al. 2004; Iamandei \& Iamandei 2005; Iamandei et al. 2005). 


\section{Methods}

All of the materials in this study were analysed macroscopically, by eye, hand loupe and a Nikon SMZ645 stereomicroscope. Representative samples of each material were thin sectioned and analysed by polarized light optical microscopy using a Nikon Eclipse E200 Pol microscope. Images were captured with a Nikon D3100 DSLR camera. In total 15 samples, from 16 sources, were analysed microscopically. The macroscopic and microscopic observations of the samples were stored in a database using standardised terminology and descriptions by Crandell (2005; 2006). One sample (from the Brad Sanitorium outcrop) was also analysed by Prompt Gamma Activation Analysis to determine its chemical composition (Crandell 2012).

\section{Results and discussions}

\subsection{Sinter}

At the source near Brad, the material has various colours, from white to yellow, red, brown or orange or even black. It is opaque, glassy or waxy (sometimes matt), with a very fine grained surface. The rock has either a very poor or a good conchoidal fracture (Ghițulescu et al. 1968). This characteristic varies significantly between samples. Still, a few hours of searching can reveal a large quantity of material suitable for knapping. The material is not as sharp as chert or jasper but is sufficient for use as a cutting or scraping tool. This material has been known about since as early as the 1800s (Zepharovich 1859: 304, 372-373) and was used up until the 1990s to produce decorative objects such as vases and bowls in workshops in the town of Brad (Ghiurcă 1981). At other locations, this material also varies in colour and lustre. At some locations it is whitish, translucent to opaque, often matt and sometimes waxy or glassy. Other samples observed were black, grey and shades of brown. The dark materials observed were almost always matt and opaque. Occasionally, materials have other combinations of visual characteristics, including some with a green colour and others with a dark, opaque, metallic, glassy appearance (See Figure 3) (Ghițulescu et al. 1968). The variations in colour are caused by the presence of Fe and Mn oxides (Ghergari et al. 1999; Pop et al. 2004; Crandell 2012). In addition to the microcrystaline quartz, this material was also observed to be comprised of microfibrous quartz, opal, and $\mathrm{Fe}$ oxyhydroxides (Figure 4). At all locations this material contains fossilised remains of molluscs and silicified remains of marshy plants, such as reeds. These remains may be visible with the eye as well as under the microscope (Figure 4 e-h). 

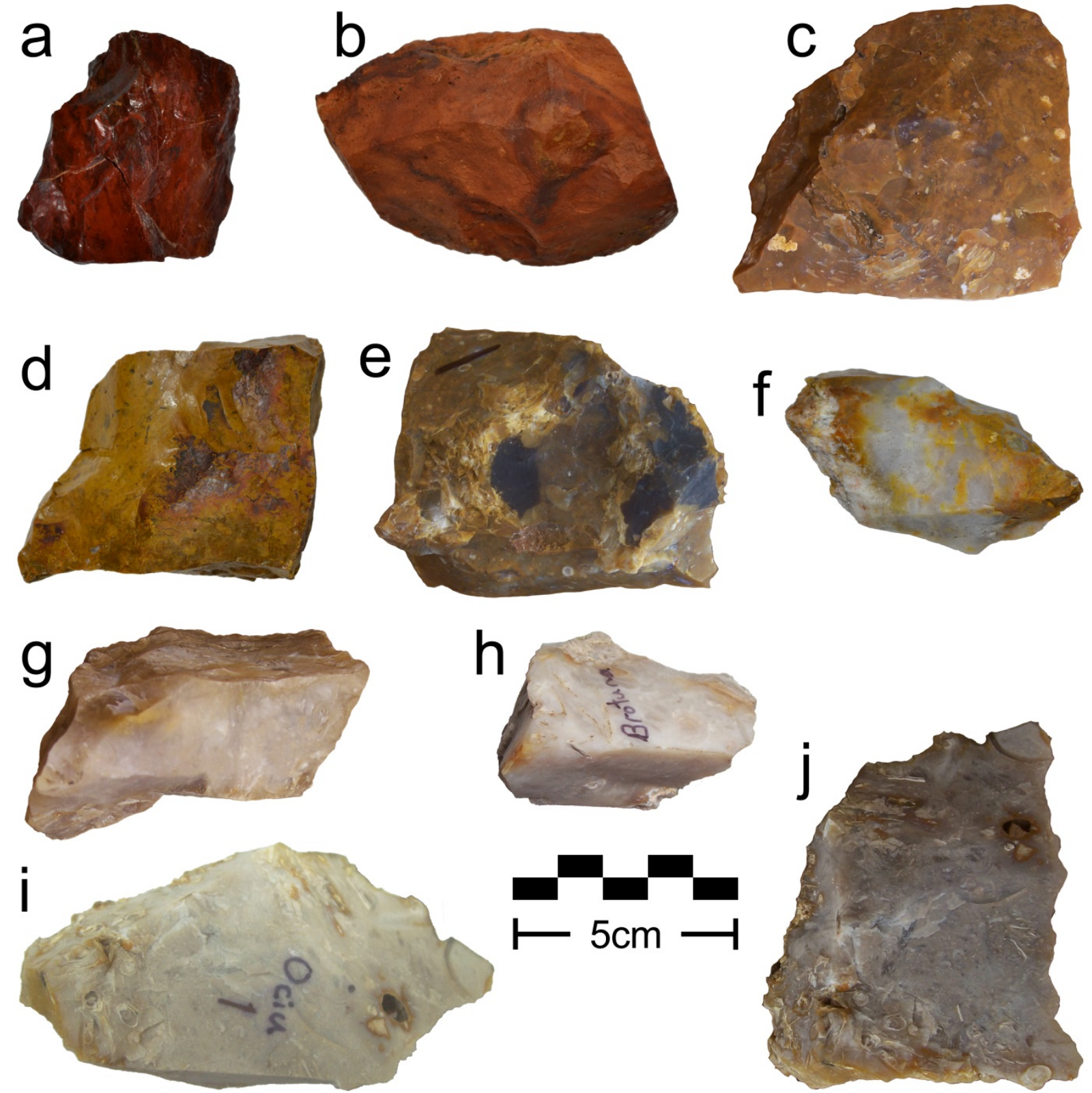

Figure 3. Photos of various colours of jasper from: a) to f) Măgura Hill (near the sanitorum), north-east of Brad; g) \& f) Brotuna; i) \& j) Ociu. 

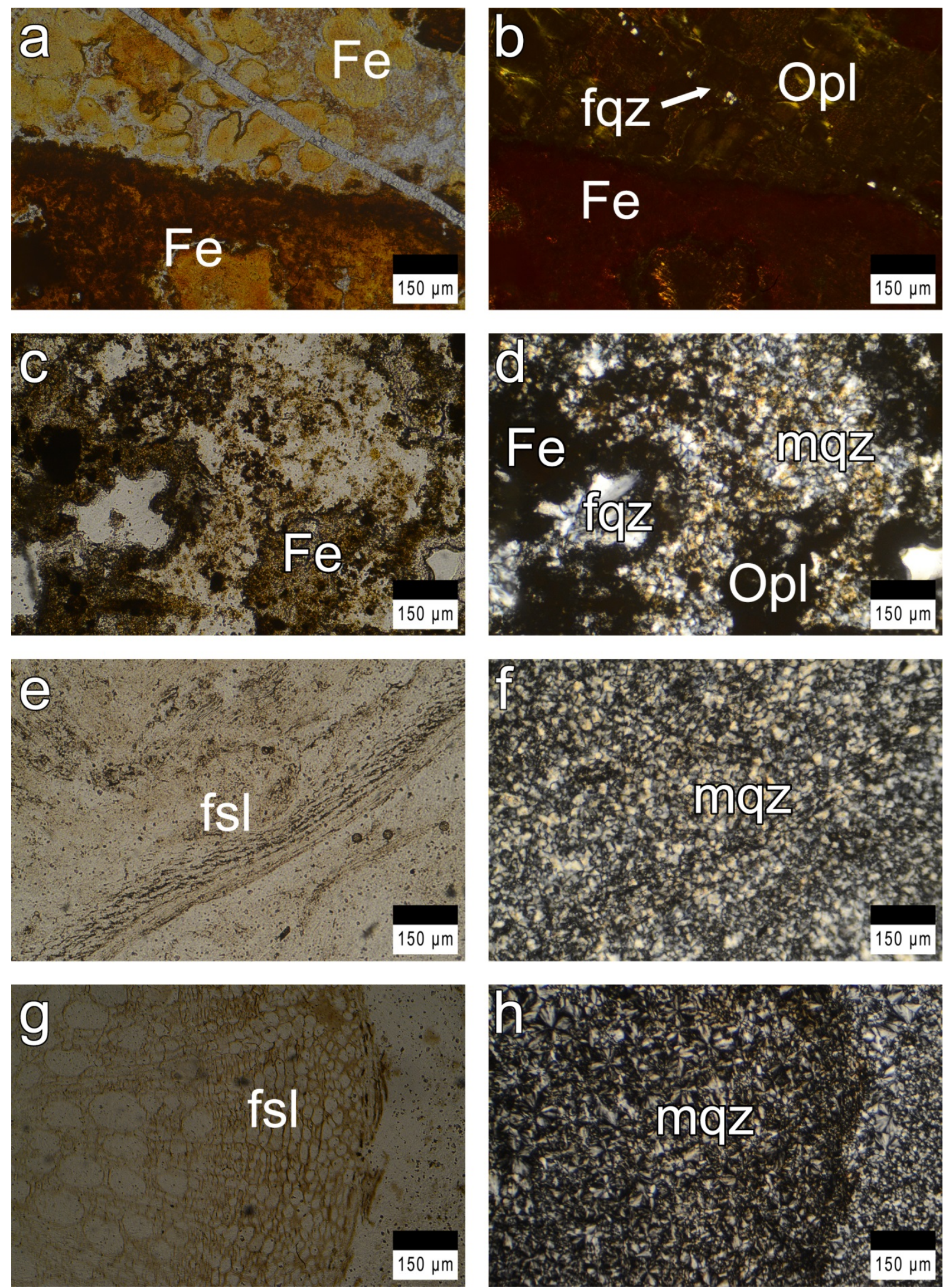

Figure 4. Microphotos (polarized light) of Criș Valley sinter (Brad jasper) from: a) \& b) Brad; c) \& d) Crișcior; e) \& f) Brotuna; g) \& h) Ociu. Left side, one polarizer (1P). Right side, the same with crossed polarizers $(+P)$. Abbreviations: Fe for Fe-rich phase, Opl for opal, mqz for microgranular quartz, fqz for fibrous quartz, fsl for fossil (plant fossils in these cases). In e and f, relic vegetal tissue replaced by later microquartz (f and h) are seen. 


\subsection{Agate}

There are numerous sources of agate within the study area but they are generally small in quantity. As well, most bands are less than a few centimetres thick and as such much of the material is unsuitable for knapping tools. Many of the agate samples from this study are housed in the Museum of Mineralogy at Babeș-Bolyai University. The agates from this area vary in colour but red is a common colour, followed by yellow. Translucency varies a lot but most pieces range from translucent to sub-translucent (for descriptions of terminology, see Crandell 2005; Crandell 2006). They may be banded in relatively flat lines or concentrically. The quartz grain size varies a lot from microscopic to macroscopic crystals. (See Figure 5.) Larger, visible crystals are more common in thicker pieces, some of which have empty areas in their centres (see Figure 5 c, for an example of large crystals). The size of the quartz crystals strongly influences how well the material breaks with a conchoidal fracture. Samples with a fine grain produce a better and more reliable conchoidal fracture. Some materials are fractured and may make the materials more difficult to knap. These last two characteristics are the main ones which determine the worth of the material for knapping.

From microscopic observations, one can quickly notice that this material is almost pure quartz (Figure 6). It appears mainly in the form of microfibrous quartz. Cracks in the material may be in-filled with larger quartz crystals or with further microfibrous quartz which formed on the walls of the crack and grew towards the centre of the crack. Banding may occur even on a microscopic scale (see Figure 6 a-d). Fe hydroxides were also observed under the microscope, with some bands containing more Fe than others, the likely cause of the variation of colour visible macroscopically in the samples.

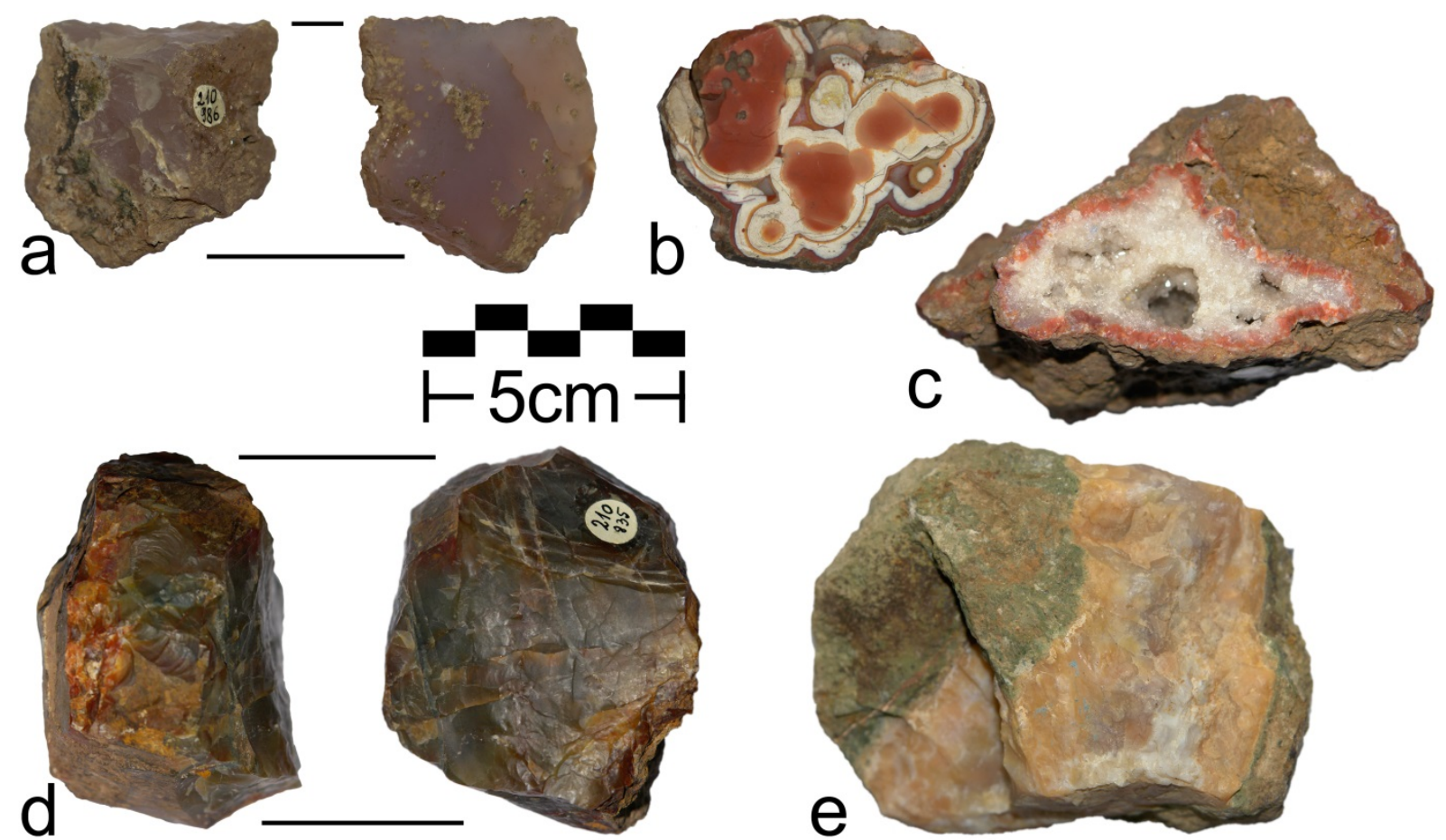

Figure 5. Agate samples from the study area. a) Brad Valley (north of Brad); b) at the edge of Brad; c) Dumbrava; d) near Brad towards Ruda; and d) near Podele. 

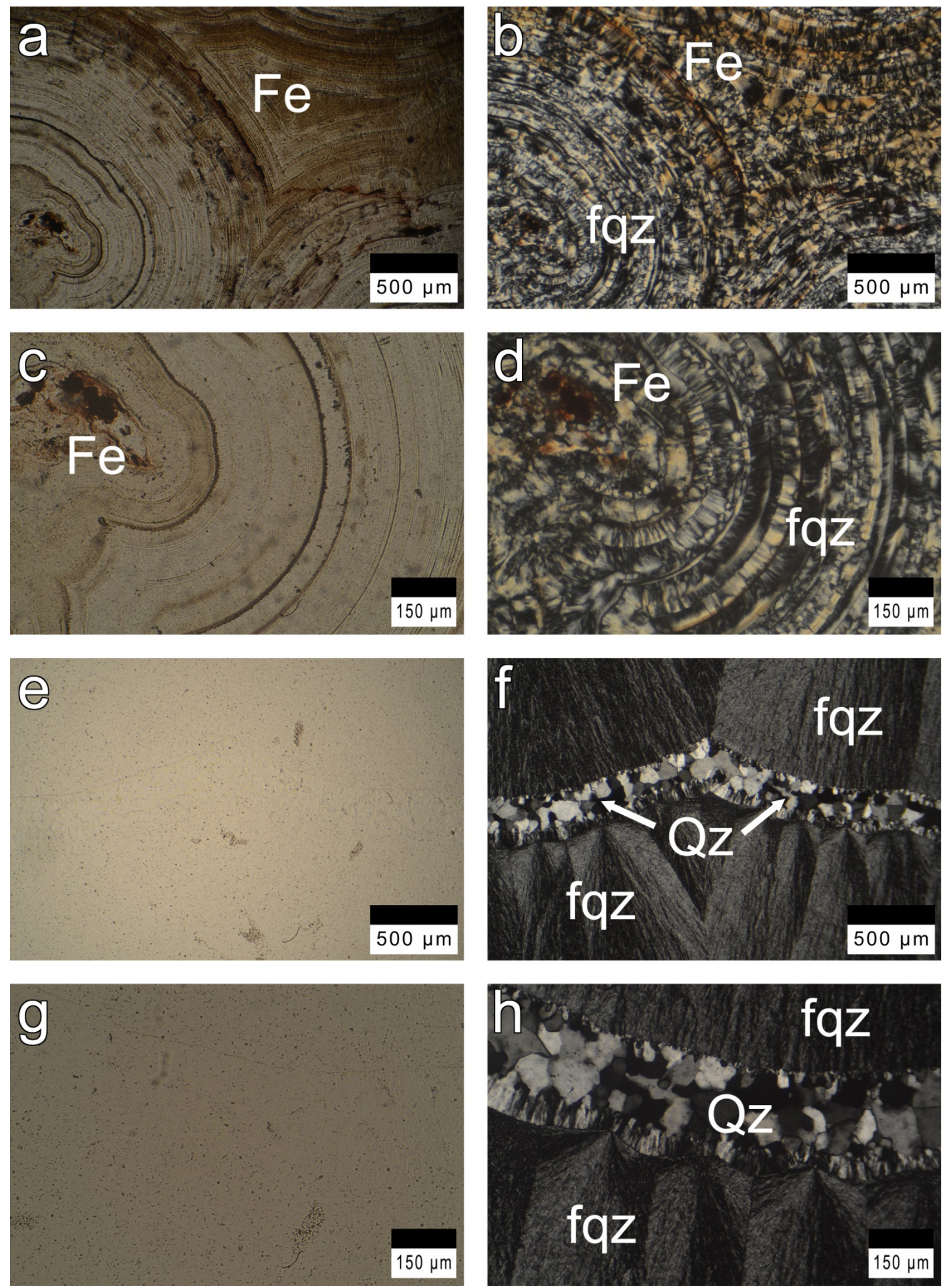

Figure 6. Microphotos (polarized light) of agate from a) to d) Brad; d) to f) Brad Valley. Left side, one polarizer (1P). Right side, the same with crossed polarizers $(+\mathrm{P})$. Abbreviations: Fe for Fe-rich phase, fqz for fibrous quartz, Qz for quartz. 


\subsection{Silicified wood}

The source of the silicified wood within the study appears to be limited to a very small area. Samples were found in situ within the remains of a petrified forest south-south-west of Ociu, at the edge of the town and the actual (living) forest. There were also found near Ociu in a valley which the local residents referred to as "Marinar" Valley, although this might not be an official designation of the valley. This valley opens to Ociu at the southern end of the town and is oriented SW-NE. It is very close to the petrified forest which is likely the source of the silicified wood found in the valley. Note that this same valley also contains sinter (Figure 3 i. and j.). Samples were also found north of the town of Prăvăleni at the location known as Culmea Cremenii (Chert Peak). Furthermore, a sample from near Basarabeasa, housed at the Museum of Mineralogy, Babeș-Bolyai University was also studied. (For locations, see the map in Figures 1 and 2.)

This material is generally poor quality for knapping tools. Some factures may be conchoidal but most area either along or perpendicular to the original grain of the wood. The edges produced by fracturing the sample were generally not sharp when compared to most other knappable materials. Many samples were also friable. (See Figure 7 for examples.) When viewed by petrographic microscope, the original structure of the wood (see Figure 8). The material is composed almost entirely of microcrystalline quartz, along with some voids filled in with microfibrous quartz (see Figure 8).

The quality of this material for tool making is low. It is described and pictured here mainly to illustrate what it is and to show why it is unlikely to have ever been used for knapping tools. Silicified wood may have been used in other areas where the material has developed more suitable characteristics.
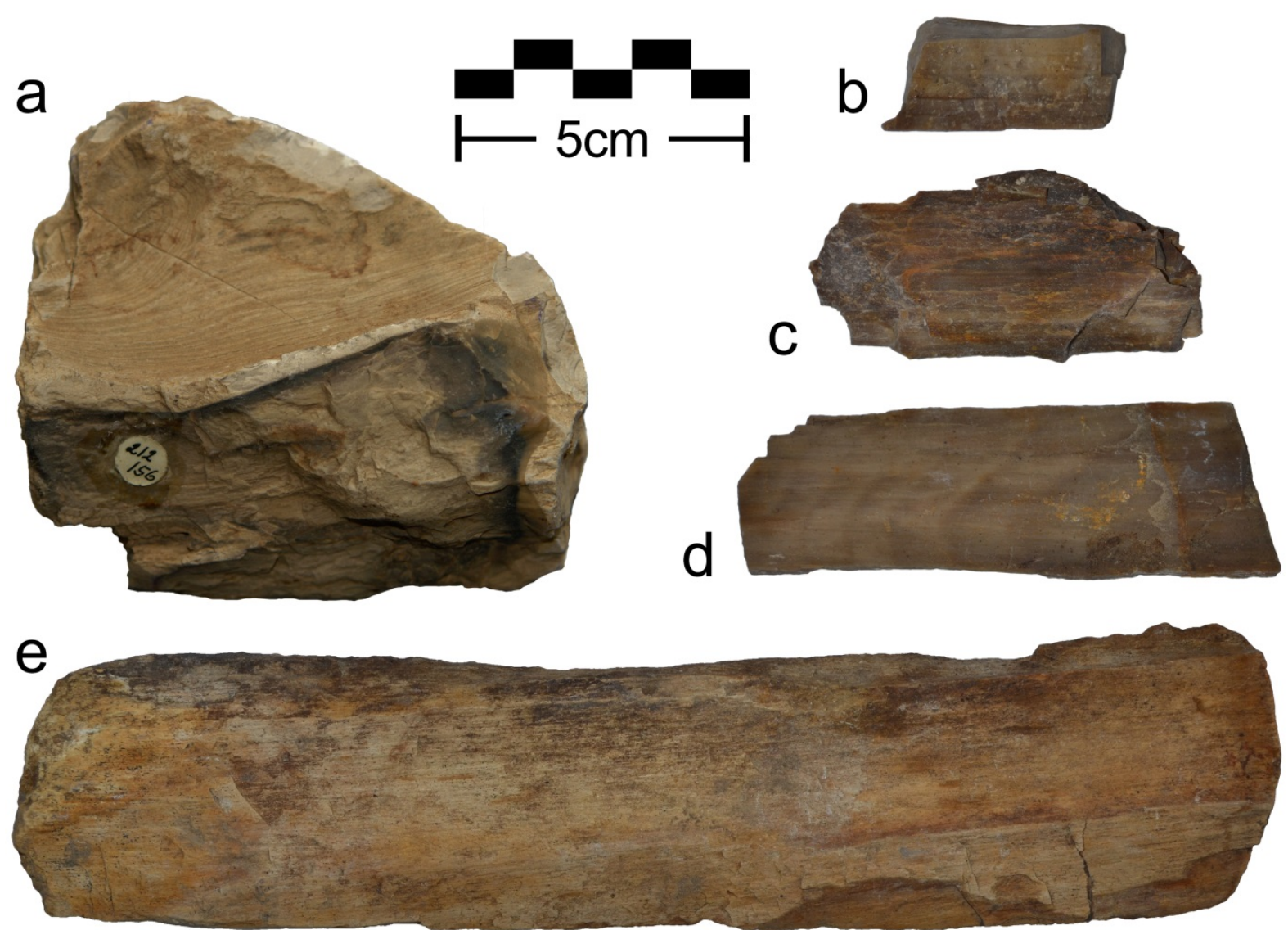

Figure 7. Silicified wood from a) Basarabeasa; b) to d) petrified forest near Ociu; e) valley south-west of Ociu. 

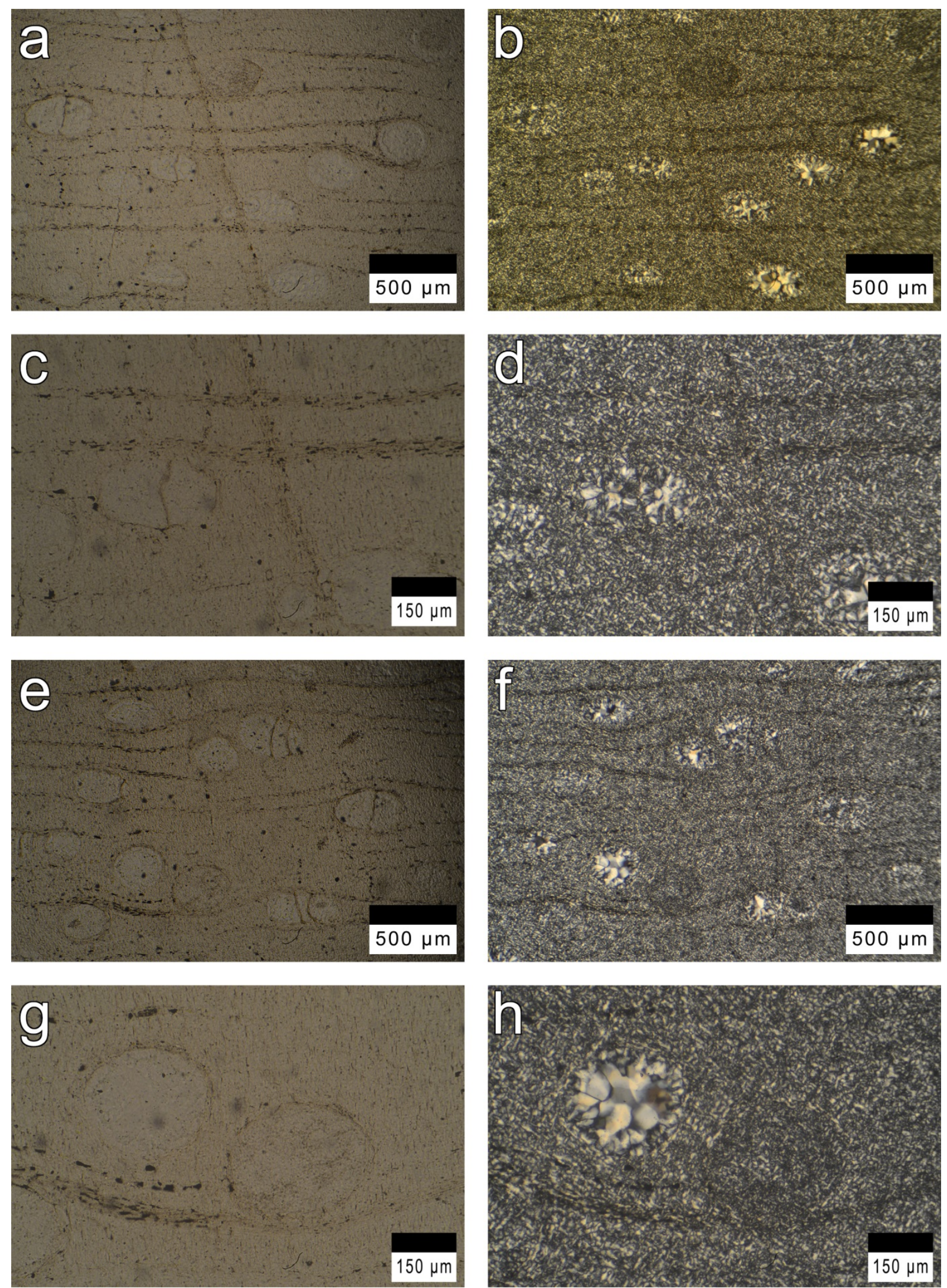

Figure 8. Microphotos (polarized light) of silicified wood from a petrified forest next to Ociu, Hunedoara county. Left side, one polarizer (1P). Right side, the same with crossed polarizers $(+\mathrm{P})$. The $1 \mathrm{P}$ images show the structure of the wood. The $+\mathrm{P}$ images show that the material is comprised almost completely of microcrystalline quartz with a few spaces filled in with microfibrous quartz. 


\subsection{Lithotheque}

The database of raw material sources is also available to researchers to compare artefacts and potential sources for provenance studies. Being able to source artefacts better will assist in determining trade routes and trade directions. In addition to recording the descriptions in of raw material sources and samples in a database, the representative physical samples collected in the field and the petrographic thin sections are included in the Romanian Lithotheque collection at Babeș-Bolyai University in Cluj-Napoca (Crandell 2009).

\section{Conclusions}

The combination of macroscopic features with microscopic features is important in any proper characterisation study of knappable materials. An objective description allows for sound interpretation in future archaeological research, in particular by assisting in identifying the sources of lithic artefacts. With the data presented here and the representative samples in the lithotheque, lithics researchers in the Criș Valley and nearby areas have reference materials which can be compared against similar characterisations of artefacts.

\section{Acknowledgements}

I would like to thank the following people who lent their assistance: Dr. Dana LüttgePop, curator at the Museum of Mineralogy, Babeș-Bolyai University, for providing access to their rock collection and inventory volumes as well as help in identifying source locations of the museums rock samples. Although most of the samples analysed were collected during fieldwork, a few (particularly the agate samples) came from the Museum of Mineralogy of Babeș-Bolyai University. Advice on fieldwork and background information about the formation of the sinter found within the study area and its parent rocks were given by Dr. Corina Ionescu. Financial support from the Romanian Ministry of Education and Research (PN-II-ID-PCE-2011-3-0881 project) is also acknowledged.

\section{References}

Alcalde-Olivares, C.a.M., C., 2002, Description microscopica de maderas fosiles del Plioceno con lignitos del Distrito Mehedinti (Sur-Oreste de Rumania). Studia UBB, Geologia, Special volume(1): 255-264.

Balintoni, I.C. 1997, Geotectonica terenurilor metamorfice din România. Carpatica, ClujNapoca, 178 p.

Berbeleac, I., David, M. \& Vanghelie, I. 1982, Stilbitul de la Valea Rea-Hățăgani. Dări de Seamă ale Ședințelor Institutul de Geologie și Geofizică, 66(1): 43-52. (in Romanian) ("Stibite from Rea-Hățăgani Valley")

Bleahu, M., Savu, H. \& Borcoș, M. 1964, Geological Map of Romania, scale 1:200,000, 17 Brad Sheet [Geological]. Romanian Geological Institute, Bucharest. (in Romanian)

Blott, S.J. \& Pye, K. 2008, Particle shape: a review and new methods of characterization and classification. Sedimentology, 55(1): 31-63. doi:10.1111/j.1365-3091.2007.00892.x

Borcoş, M., Popescu, G. \& Roșu, E. 1986, Nouvelles données sur la stratigraphie et l'évolution du volcanisme tertiaire des Monts Métallifères. Dări de Seamă ale Şedinţelor Institutul de Geologie și Geofizică, 70-71(4): 245-259. (in French) ("New data on the stratigraphy and evolution of Tertiary volcanism of the Ore Metaliferi Mountains") 
Bordea, S. \& Borcoș, M. 1972, Geological Map of Romania, scale 1:50000, 73d Brad Sheet. Romanian Geological Institute, Bucharest. (in Romanian)

Bulgariu, B., M., B., Jitaru, R., Bulgariu, L., Pintilei, M. \& Popescu, C. 2005, Contributions to the study of chalcedony and opal quartered in the andesites from Bucuresci-Criscior perimeter (Brad, Hunedoara county) - Part 1. Analele științifice ale Universității" Al. I. Cuza" din Iaşi: Geologie, 51: 27-44.

Cioflica, G., Savu, H., Nicolae, I., Lupu, M. \& Vlad, Ş. 1981, Alpine ophiolitic complexes in South Carpathians and South Apuseni Mountains : guide to excursion A3. CarpathoBalkan Geological Association, XII Congress, Bucharest-Romania. Institute of Geology and Geophysics, Bucharest, 80 p.

Constantina, C. \& Pop, D. 2003, Brief overview on the $\mathrm{SiO}_{2}$ varieties of gem-quality from Southern Apuseni Mountains (Romania). Acta Mineralogica-Petrographica, Abstract Series, Szeged, 1: 21.

Crandell, O.N. 2005, Macroscopic analysis and characterisation of chert for provenance purposes. Sargetia, Acta Musei Devensis, 33: 137-153.

Crandell, O.N. 2006, Macroscopic and microscopic analysis of chert; A proposal for standardisation of methodology and terminology. Buletinul Cercurilor Științifice Studențești, 12: 7-30.

Crandell, O.N. 2009, Romanian Lithotheque Project: Knappable stone resources in the Mureș Valley, Romania. Studia Geologia, Special Issue, MAEGS - 16: 79-80. URL:

http://www.studia.ubbcluj.ro/arhiva/abstract_en.php?editie=GEOLOGIA\&nr=Special\% 20Issue\&an=2009\&id_art=7388

Crandell, O.N. 2012, Evaluation of PGAA data for provenance of lithic artifacts. Studia UBB, Geologia, 57(1): 3-11. doi:10.5038/1937-8602.57.1.1

Dimitrescu, R. 1958, Studiul geologic și petrografic al regiunii dintre Gîrda și Lupșa (basinul superior al Arieșului). Anuarul Comitetului Geologic, 31: 51-129. (in Romanian) ("Geological and petrographic study of the region between Gîrda and Lupșa (upper basin of the Arieș)")

Flörke, O.W., Köhler-Herbertz, B., Langer, K. \& Tönges, I. 1982, Water in microcrystalline quartz of volcanic origin: Agates. Contributions to Mineralogy and Petrology, 80(4): 324-333. doi:10.1007/bf00378005

Folk, R.L. \& Weaver, C.E. 1952, A study of the texture and composition of chert. American Journal of Science, 250(7): 498-510. doi:10.2475/ajs.250.7.498

Ghergari, L. \& Ionescu, C. 1999, Genetic considerations on jasper in the Brad area (Apuseni Mts., Romania). Romanian Journal of Mineralogy, Supplement 1, 79: 32.

Ghergari, L., Ionescu, C. \& Püspöki, Z. 1999, Jasper occurrences in the Brad area, Apuseni Mountains (Romania). Gems and gemology, 35(3): 139-140.

Ghițulescu, T.P. \& Borcoș, M. 1966, Încadrarea funcțională a magmatismului alpin din Munții Metaliferi. Studii și Cercetări de Geologie, Geofizică, Geografie. Seria Geologie, 11(2): 267-279. (in Romanian) ("Functional classification of the alpine magmatism in the Metaliferi Mountains")

Ghițulescu, T.P., Verdeș, G. \& Chința, R. 1968, Zăcămintele de silicolite din bazinul neogen al Bradului (jud. Hunedoara). Studii și Cercetări de Geologie, Geofizică, Geografie. 
Seria Geologie, 13(1): 67-76. (in Romanian) ("Chert ore deposits in the Neogene basin of Brad (Hunedoara county)")

Ghiurcă, V. 1981, Câteva date geologice asupra silicolitelor semipreţioase din jud. Hunedoara. Studia UBB Geologia-Geographia, 26(1): 42-47.

Ghiurcă, V. 2000, Aria de apariție a mineralelor silicioase de pe Culoarul Mureșului (HD). Acta (Siculica), 2000(1): 21-38. (in Romanian) ("Area of occurrence of siliceous minerals along the Mureș Corridor (HD)")

Givulescu, R. 1997, Istoria padurilor fosile din Terţiarul Transilvaniei, Banatului, Crişanei şi Maramureşului. Carpatica, Cluj-Napoca, 172 p.

Graetsch, H.A. 1994, Structural characteristics of opaline and microcrystalline silica minerals. In: Silica; Physcial Behavior, Geochemistry, and Materials Applications (Heaney, P.J., Prewitt, C.T. \& Gibbs, G.V., Eds.) Reviews in Minerology Vol. 29, Mineralogical Society of America, Chantilly, VA: p. 209-232.

Graetsch, H.A., Flörke, O.W. \& Miehe, G. 1985, The nature of water in chalcedony and opalC from brazilian agate geodes. Physics and Chemistry of Minerals, 12(5): 300-306. doi:10.1007/bf00310343

Heaney, P.J. 1993, A proposed mechanism for the growth of chalcedony. Contributions to Mineralogy and Petrology, 115(1): 66-74. doi:10.1007/bf00712979

Heaney, P.J. \& Davis, A.M. 1995, Observation and origin of self-organized textures in agates. Science, 269(5230): 1562-1565. doi:10.1126/science.269.5230.1562

Iamandei, S. \& Iamandei, E. 1997, New Fossil Dicots in Pyrrhoclastics of Prăvăleni, Metalliferous Mountains. Acta Paleontologica Romaniae, 1, 113-118.

Iamandei, S. \& Iamandei, E. 1999, Liquidambaroxylon pravalense n.sp., in the Pyroclastics of Prăvăleni, Metalliferous Mts. Acta Horti Botanicae Bucureştiensis, 27, 223-232.

Iamandei, S. \& Iamandei, E. 2000, Fossil conifer wood from Pravaleni-Ociu, Metalliferous Mts. Acta Palaeontologica Romaniae, 2: 201-212.

Iamandei, S. \& Iamandei, E. 2001, New Juglandaceous fossil wood in the Middle Miocene lignoflora of Pravaleni-Ociu (South Apuseni). In: 3rd Romanian National Symposium of Palaeontology. Acta Palaeontologica Romaniae. Vasiliana '98 (Olaru, L., Ed.), Iaşi: p. 185-198.

Iamandei, S. \& Iamandei, E. 2005, Fossil Salicaceae from the Badenian Petrified Forest from Prăvăleni-Ociu,South Apuseni Mts. Revue Roumaine de Géologie, 49, 57-61.

Iamandei, S., Iamandei, E. \& Țibuleac, P. 2004, New fossil wood from the Late Badenian Forest of. Prăvăleni, Metalliferous Mts.(1st Part). Analele ştiinţifice ale Univ. "Al. I. Cuza” Iaşi, Geologie, , XLIX-L(2003-2004): 235-245.

Iamandei, S., Iamandei, E. \& Ţibuleac, P. 2005, New fossil wood from the Late Badenian Forest of Prăvăleni, Metalliferous Mts. (2nd Part). Analele ştiinţifice ale Univ. "Al. I. Cuza" Iaşi, Geologie, LI, 111-120.

Ianovici, V., Borcoș, M., Bleahu, M., Patrulius, D., Lupu, M., Dimitrescu, R. \& Savu, I. 1976, Geologia Munților Apuseni. Editura Academiei Republicii Socialiste România, Bucharest, 632 p. (in Romanian) ("Geology of the Apuseni Mountains")

Ianovici, V., Giuşcă, D., Ghiţulescu, T.P., Boreos, M., Lupu, M., Bleahu, M. \& Savu., H. 1969, Evoluția geologică a Munților Metaliferi. Editura Academiei Republicii 
Socialiste România, Bucharest, 743 p. (in Romanian) ("Geological evolution of the Metaliferi Mountains")

Lupu, M., Borcoș, M., Dimian, M., Lupu, D. \& Dimitrescu, R. 1966, Geological Map of Romania, scale 1:200,000, 18 Turda Sheet. Romanian Geological Institute, Bucharest. (in Romanian)

Mârza, I. \& Constantina, C. 2000, Minerale geme asociate genetic ofiolitelor mezozoice si gheizeritelor neogene, din Muntii Apuseni de Sud. Studia UBB, Geologia, 45(1): 91104. (in Romanian) ("Gem minerals genetically associated with Mesozoic ofiolites and Neogene geyserites, from the Southern Apuseni Mountains")

Mârza, I., Ghergari, L. \& Lázlo, C. 1989, Liesegang structures hydrothermal-metasomatic in the pebbles of Badenian conglomerates from the polymetallic ore deposit at BaiagaCoranda Hondol, the Metalliferous Mts. Studia UBB Geologia-Geographia, 43(1): 8796.

Moxon, T. \& Reed, S.J.B. 2006, Agate and chalcedony from igneous and sedimentary hosts aged from 13 to 3480 Ma: a cathodoluminescence study. Mineralogical Magazine, 70(5): 485-498. doi:10.1180/0026461067050347

Moxon, T., Reed, S.J.B. \& Zhang, M. 2007, Metamorphic effects on agate found near the Shap granite, Cumbria, England: as demonstrated by petrography, X-ray diffraction and spectroscopic methods. Mineralogical Magazine, 71(4): 461-476. doi:10.1180/minmag.2007.071.4.461

Nagy, F. \& Mârza, I. 1967, Magnolioxylon transilvanicum sp. n. în cineritele de la Prăvăleni. Analele Universităţii de la Bucureşti, s. Şt. Nat., Geol.-Geogr., 16(1): 97-102.

Nagy, F., Petrescu, I. \& Mârza, I. 2002, La Présence d'un Bois de Glyptostroboxylon dans le Miocène de Prăvăleni - Brad Contribuţii Botanice, 37: 293-298. (in French) ("Abstract: The Presence of Fossil Wood of Glyptostroboxylon in the Miocene from PrăvăleniBrad")

Petrescu, I. \& Nuţu, A. 1969, Asupra unui lemn de Alnoxylon in colecţia Muzeului Deva. Sargetia, Acta Musei Devensis, sr. Sc. Nat., 6: 223-229.

Petrescu, I. \& Nuţu, A. 1970, Alte tipuri de lemne din Miocenul superior de la PrăvăleniBrad. Sargetia, Acta Musei Devensis, sr. Sc. Nat., 7: 253-258.

Petrescu, I. \& Nuţu, A. 1972, Asupra unui lemn de Icacinoxylon Shlk., în Miocenul superior de la Prăvăleni-Brad, Sargetia (Acta Mesei Devensis), s. Ştiinţele Naturii, Deva, IX: 7779.

Pop, D., Constantina, C., Tătar, D. \& Kiefer, W. 2004, Raman spectroscopy on gem-quality microcrystalline and amorphous silica varieties from Romania. Studia UBB, Geologia, 49(1): 41-52. URL: http://scholarcommons.usf.edu/geologia/vol49/iss1/art4

Russo-Săndulescu, D., Berza, T., Bratosin, I. \& Ianc, R. 1976, Contribuții la studiul petrologic al unor magmatite alpine din nordul Munților Trascău. Dări de Seamă ale Ședințelor Institutul de Geologie și Geofizică, 62(1): 165-194. (in Romanian) ("Contributions to the petrological study of some alpine magmatite from the northern Trascău Mountains")

Săndulescu, M., Kräutner, H., Borcoş, M., Năstăseanu, S., Patrulius, D., Ștefănescu, M., Ghenea, C., Lupu, M., Savu, H., Bercia, I. \& Marinescu, F. 1978, Geological map of Romania, 1:1,000,000 scale. Institute of Geology and Geophysics, Bucharest. (in Romanian) 
Săndulescu, M.I.V. 1984, Geotectonica României. Editura Tehnică, Bucharest, 336 p.

Savu, H. 1980, Genesis of the Alpine Cycle Ophiolites from Romania and Their Associated Calc-Alkaline and Alkaline Volcanics. Anuarul Institutului de Geologie și Geofizică, 56: 55-57.

Savu, H. 1983, Geotectonic and magmatic evolution of the Mures Zone (Apuseni Mountains) - Romania. Anuarul Institutului de Geologie şi Geofizică, 61: 159-168.

Sneed, E.D. \& Folk, R.L. 1958, Pebbles in the Lower Colorado River, Texas a study in particle morphogenesis. The Journal of Geology, 66(2): 114-150. URL: http://www.jstor.org/stable/30058239

Socolescu, M.M. 1944, Les affleurements de minerais de la région de Vaţa-Soimuş-BuceavaSăvârşin-Zam (départements de Hunedoara et d'Arad). Comptes Rendus des Séances, Institut Géologique de Roumanie, 28: 93-125. (in French) ("Ore outcrops of the VaţaSoimuş-Buceava-Săvârşin-Zam region (Hunedoara and Arad counties)")

SRTM 2000, Shuttle Radar Topography Mission (SRTM) Digital Elevation Models (DEMs). NGA (National Geospatial-Intelligence Agency) and NASA (National Aeronautics and Space Administration). Retrieved 15 March 2010. URL:

http://dds.cr.usgs.gov/srtm/version2_1/

Ştefan, A., Istrate, G. \& Udrescu, C. 1982, Studiul petrologic al banatitelor din regiunea Măgureaua Vaței-valea Birtinului (Apusenii de Sud). Dări de Seamă ale Ședințelor Institutul de Geologie și Geofizică, 67(1): 145-174. (in Romanian) ("Petrological study of banatites from the Măgureaua Vaței-valea Birtinului region (Southern Apuseni Mts.)")

Tudor, G. 2009, GIR bedrock and superficial lithostratigraphy. Geological Survey of Romania. Retrieved 15 March 2013. URL: http://37.128.225.60/ArcGIS_Server_IGR/services/GIR_Bedrock_and_Superficial_Lith ostratigraphy/MapServer/WMSServer?

Turq, A. 2005, Réflexions méthodologiques sur les études de matières premières lithiques. 1 des lithothèques au matériel archéologique. Paléo. Revue d'archéologie préhistorique, (17): 111-132. (in French) ("Methodological considerations about lithic studies. 1 - from lithotheques to archaeological samples") URL: http://paleo.revues.org/883

Voiteşti, I.P. 1934, La mylonite du confluent des deux Someș, pres Gilău sur la bordure orientale des M-ts Apuseni. Revista Muzeului Geologic-Mineralogic al Universităt, ii din Cluj, 5(1): -162-202. (in French) ("Mylonite from the confluence of the two Someş Rivers, near Gilău on the eastern edge of Apuseni Mts.")

Zepharovich, V. 1859, Mineralogisches Lexicon für das Kaiserthum Österreich. Vol. 1. Wilhelm Braumüller, Vienna, 630 p. (in German) ("Mineralogical lexicon of the Austrian Empire")

Zingg, T. 1935, Beitrag zur Schotteranalyse : die Schotteranalyse und ihre Anwendung auf die Glattalschotter. Schweizer Mineralogische und Petrographische Mitteilungen, 15(1): 39-140. (in German) ("Contribution to Gravel Analysis") doi:10.5169/seals-15330 